\title{
Analysis on the Quality Change of Tempeh, Catfish and Fried Chicken as the Effect of the Repetitive Used Cooking Oil
}

\author{
Rina Rifqie Mariana ${ }^{1}$, Titi Mutiara Kirana $^{1} \&$ Laily Hidayati $^{1}$ \\ ${ }^{1}$ Study Program of Tata Boga, Department of Industrial Technology, State University of Malang, Indonesia \\ Correspondence: Titi Mutiara Kirana, Study Program of Tata Boga, Department of Industrial Technology, State \\ University of Malang, Indonesia. E-mail: mutiaraum@yahoo.co.id
}

Received: November 26, 2013 Accepted: December 26, 2013 Online Published: January 6, 2014

doi:10.5539/jfr.v3n1p96

URL: http://dx.doi.org/10.5539/jfr.v3n1p96

\begin{abstract}
The aim of this study is to analyze the change of product characteristic that will be fried using the cooking oil that is repetitively used by the sidewalk vendors (locally abbreviated as PKL). In this study, Randomized Complete Block Design (RCBD) was used and divided into 2 factors: types of product consisting of 3 levels (fried chicken, fried catfish and fried tempeh (Indonesian dish made of deep-fried fermented soya beans)) and frying frequency (control, $4^{\text {th }}$ frying, $6^{\text {th }}$ frying and $8^{\text {th }}$ frying). Once obtained, the data would be analyzed using ANOVA (Analysis of variance) method in which if an interaction is found, it would be continued by DMRT (Duncan's Multiple Range Test) using confidence interval at 5\%. The result of the research shows that the types of product and the usage of repetitively used cooking oil at the different frequencies will bring an effect on the product quality after a repetitive frying by causing a significantly different impact $(\alpha=0$. 05) on water level, nutrient level, peroxide number, TBA level, p-Anisidine number at 0,38 , and free fatty acid levels.
\end{abstract}

Keywords: locally abbreviated, peroxide, TBA, p-Anisidine, FFA

\section{Introduction}

Frying is a very popular way of food processing. It can be defined as a process of cooking and a products using heat in the form of oil as a media of heat transfer. When a food product is fried using heated cooking oil, a number of complex reactions occur in the cooking oil that, in turn, will lead to damage. During the frying process at high temperature, the air and water contained in the product will badly affect the oil. The reaction between product and oil has, in turn, caused a very complex reaction and will form volatile and nonvolatile compounds indicating that the cooking oil is already on damage.

Frying is a process to cook foodstuff using food fats and oil. This commonly begins by pouring cooking oil into a frying pan to be heated. This then is followed by putting the foodstuff to be fried. The process, besides resulting in a fried foodstuff, also results in vapor released from fat and byproduct of fat arising out of heating, frying and encrustation. A number of factors, afterwards, bring any effects on the frying condition in frying pan that is heating due to the presence of air, local over heating of fat, aeration of the fats, contact of fat and metal from the frying pan, contact of foodstuff and oil, and presence of crust and burnt particles. Here, of the aforementioned factors, the heating with the presence of air becomes the most significant factor (Raharjo, 2008).

A frying process will cause a decomposition of fatty acids that at certain level can make the cooking oil unusable. Frying oil, in essence, refers to triglyceride that in a fresh condition (before used to fry) possesses certain fatty acids. However, a quite high volume of oil and a repetitive use on it can decrease the quality of frying results. A fatty oxidizing process is an unexpected process that can lead to the reduction in quality. An over-oxidizing process in body is assumed to be a causal factor of certain diseases such as cardiovascular, cancer, early aging, or cataract.

The quality of the cooking oil is highly determined by its fatty acid components that can impact on the physical and chemical natures and the oil stability during the frying process. According to Almatsier (2005), triglyceride of oil or fat approximately contains $94-96 \%$ of fatty acid. In addition to its fatty acid components, the stability of cooking oil is also influenced by its unsaturated fatty acid, spread of double binding of its fatty acid, and any substances that can accelerate or decelerate the occurrence of damage process of cooking oil already exist in nature or added intentionally. 
The increasing sidewalk vendors of fried food such as catfish, chicken and tempeh using repetitive used cooking oil can decrease the product quality and becomes harmful for health. In a frying process, the cooking oil functions as a medium of transferring heat, making flavor crispier, and adding nutrients and calories in foodstuff. On the other hand, the repetitively used cooking oil can decrease the quality and even be harmful for health. This is because the use of cooking oil in a long period without any substitution on it with the new one will generate a series of reactions such as hydrolysis, thermal oxidation and thermal polymerization (Aidos et al., 2001).

When cooking oil is being used, a change in the physico-chemical feature of oil will occur. This change will impact on the product quality. Moreover, this change is also related to the product safety. In response, a number of nutritionists have been so long doing any examinations to identify the indicators of an accurate oil quality (Aidos et al., 2001). Several tests have been recommended as the accurate indicators such as polar components (TPM) and polymer. In addition, there are any other tests commonly used by some wok industries such as peroxide, free fatty acid, viscosities, anisidine, and color.

Free fatty acid level in this case refers to a characteristic most commonly used as a controller of oil quality. It is a determination of the number of fatty acid number as a result of hydrolysis of triglyceride binding that is not degraded yet into a component that is not titrated or probably is formed through the oxidizing process.

Meanwhile, peroxide numbers are the most widely used method to determine the oil degradation level. The primary oxidized product of oil is hydro-peroxide. Peroxide can be quantitatively calculated by determining the number of iodines released through the peroxide reaction with KI. Fresh cooking oil that has been deodorized should have a peroxide value at zero. In most cases, the cooking oil is assumed to have a good ability in storage if having a value of peroxide number at $1,0 \mathrm{meq} / \mathrm{kg}$.

Malonaldehida (MDA) is a secondary oxidation product that is toxic towards living cells. It is an initiator, carcinogen, and mutagen. It also can be bound with lipid and protein and inactivate ribonuclease and covalently is bond with nucleic acid (Aidos et al., 2001).

In a cellular system, fat oxidation plays a very essential role - particularly in the part of membrane where enzymes are activated by oxygen exist. As a result, these enzymes play a role towards the oxidative stress that leads to the formation of active oxygen such as superoxide $\left(\mathrm{O}_{2}\right)$, hydroxyl radical $(\mathrm{OH})$, hydrogen peroxide $\left(\mathrm{H}_{2} \mathrm{O}_{2}\right)$, and singlet oxygen. Fat oxidation in membrane can cause damage on membrane structure as well as on organelle in cells. In addition, the receptor present in the membrane can be released or activated. The secondary effect of fat oxidation is the initiation of free radical reaction originated from peroxide diffused in cells or transported through blood stream.

Hydroxyalkenal, product of fat oxidation, has an ability to be covalently bond with nucleic acid and to inducting the change of DNA. This compound is chemotactic inducting the inflammatory reaction.

Furthermore, the fat oxidation activates the process of cell death through the degradation of cellular components and the activation of cellular immune system. The induction of fat oxidation has been related to a number of diseases such as haemochromatosis, Keshan disease, rheumatic arthritis, atherosclerosis, ischemia heart disease (IHD), aging, cancer formation, and cardiovascular disease. The oxidized products at the risk of various diseases can be originated from food or endogenously produced by body. These products inducts the tumor formation, stimulates atherosclerosis, genotoxic and cytotoxic.

\section{Material and Methods}

This research was conducted in the period of September-October 2013 at the Laboratory of Biotechnology, Universitas Brawijaya Malang. Randomized Complete Block Design (RCBD) was used as the design of the experiment consisting of 2 factors: type of products divided into 4 levels (fried chicken, fried catfish, fried duck, and fried tempeh) and frequency of frying (control, second frying, fourth frying, sixth frying and eighth frying). The obtained data subsequently was analyzed using ANOVA (analysis of Variance). Furthermore, if an interaction was found, it would be continued with DMRT (Duncan's Multiple Range Test) using confidence interval at $5 \%$.

Meanwhile, the tests both on the protein level and on fat level were done using Kjeldahl Semi-micro Method and Oil Extracting Procedure using Bligh and Dryer Modification Method, respectively. The test on water level, on the other hand, was done using oven method (AOAC), Procedure of Free Fatty Acid Analysis, Procedure of Oxidation Analysis using the method of Hills and Thiel modified by Chapman and Mackay, Procedure of p-Anisidine number analysis, Procedure of thio-barbituric acid (TBA) number analysis. 


\section{Result and Discussion}

\subsection{Water Level}

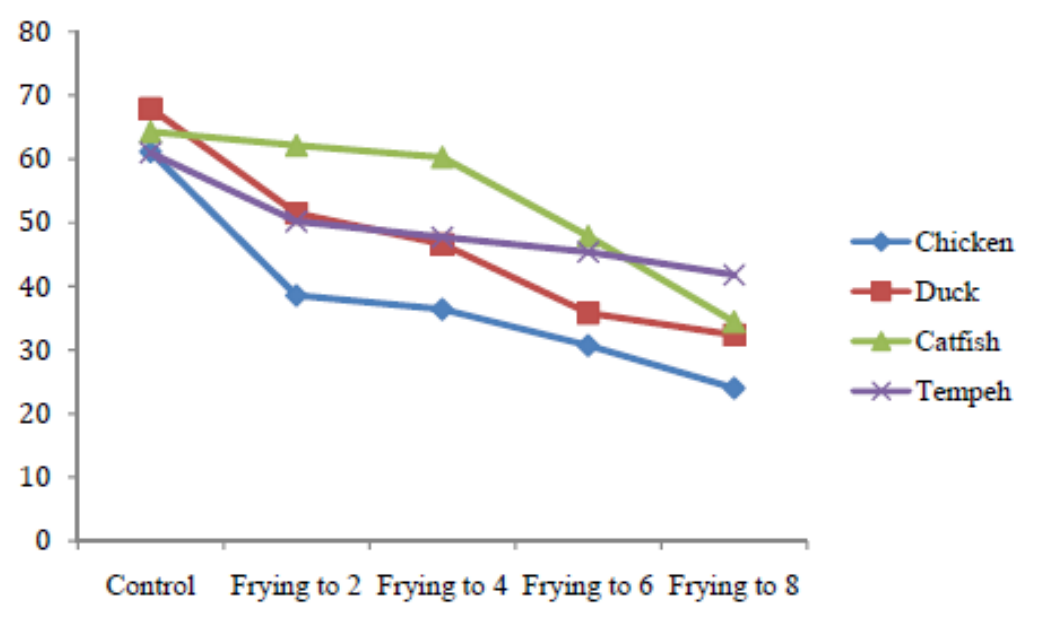

Figure 1. The treatment in the repetitive use of cooking oil on the water level

Figure 1 illustrates that the treatment in the repetitive use of cooking oil will have a significant effect $(\mathrm{P}<0.05)$ on the water level of product. This decrease of water level is due to the water contained in the material steaming; thus the one absorbed into the foodstuff is oil. When the oil absorption increases, the water level will decrease as the position of water is replaced by oil as a media of heat transfer. This occurs due to the temperature and the length of frying process. Aidos et al. (2001) argue that the oil absorption will increase along with the increase of the frequency of repetitive use of cooking oil. Aidos et al. (2001) said that the oil absorption by fried products is highly influenced by several factors: 1) temperature and time directly proportional with the increase of oil volume absorbed by fried product, (2) water contained in the foodstuff that will be replaced by oil during the frying process and (3) the quality of oil being used. Even, the type of foodstuffs being fried also will influence the oil absorption. In this case, the fried products originated from the vegetable foodstuffs and contain starch will absorb more oils compared to the animal foodstuffs.

Based on the graph above, it can be seen that the higher the frying frequency, the lower the water level of the fried foodstuffs in which the water level of the foodstuff can be illustrated as follows: fried catfish $>$ fried duck $>$ fried chicken $>$ fried tempeh. The released water from the fried products can be shown through the ones drier compared to others that have not been dried yet.

The result of data analysis shows a significantly different result $(a=0.05)$ between the frying frequency and the fried products during the first frying process to the eighth one. The analysis result also shows how water level decreased started from the first frying to the last one in each product. The high water content in a material has made the endurance of the material low. To lengthen the endurance of a material, a part of water must be removed through certain ways depending on the types of the material itself (Winarno, 2004).

Winarno (2004) stated that during the frying process, some changes occur such as the formation of aroma, color change and decrease of water level and fried products. The difference of time and temperature in frying also will influences the extent of water releasing from the material. 


\subsection{Fat Level}

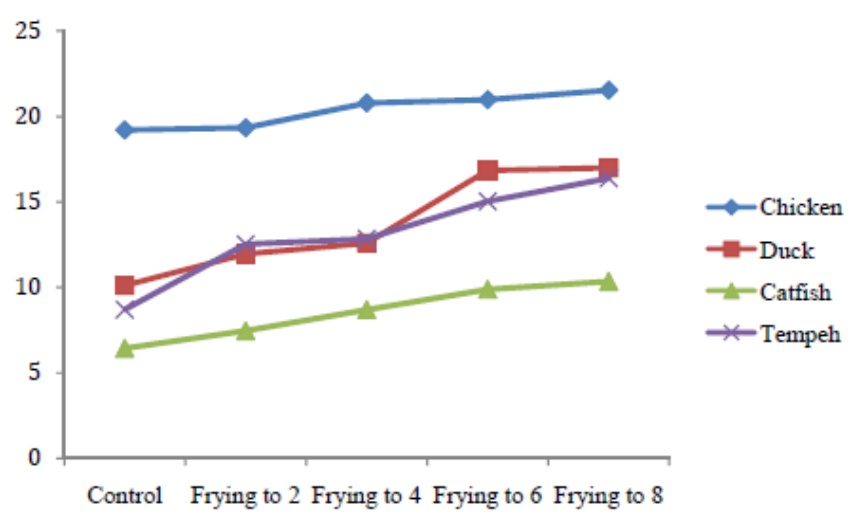

Figure 2. The graph of fat level of products of fried chicken, fried duck, fried catfish, and fried tempeh at any different frying frequencies

Figure 2 illustrates that the treatment of cooking oil in a repetitive use will significantly influence the fat level of the product $(\mathrm{P}<0.05)$.

The increase of the fat level occurs due to the oil absorption from the cooking oil used in that, during the frying process, the amount of oil mostly are trapped inside. Therefore, the foodstuff will lose its water content and the oil will enter to the cavity because of the temperature effect. In this way, the oil will be absorbed into the material and the viscosity of the repetitively used cooking oil will be getting thicker - leading the oil residue on the foodstuff in increase. This is in line with what argued by Ericson (2002) that the oil absorption will increase in a more frequently repetitive use of cooking oil. Aidos et al. (2001) also added that the use of cooking oil in frying process now is more increasing due to its characteristic as a heat conductor.

The result of analysis on the oil absorption shows an increase in each fried product in a repetitive frying. The highest percentage of oil absorption of fried food product is found in tempeh reaching at $46,90 \%$. By contrast, the lowest percentage in the level of oil absorption from fried foodstuff is found on fried chicken at $10.8 \%$.

Oil absorption refers to the amount of oil absorbed into the food during the frying process. From the obtained data, it is found that the increasing percentage in oil absorption occurs due to the high heating temperature and the long period of cooking oil use. This is in line with what Ericson (2002) that the fried food can have an increase of oil absorption due to the long period of frying process.

\subsection{Protein Level}

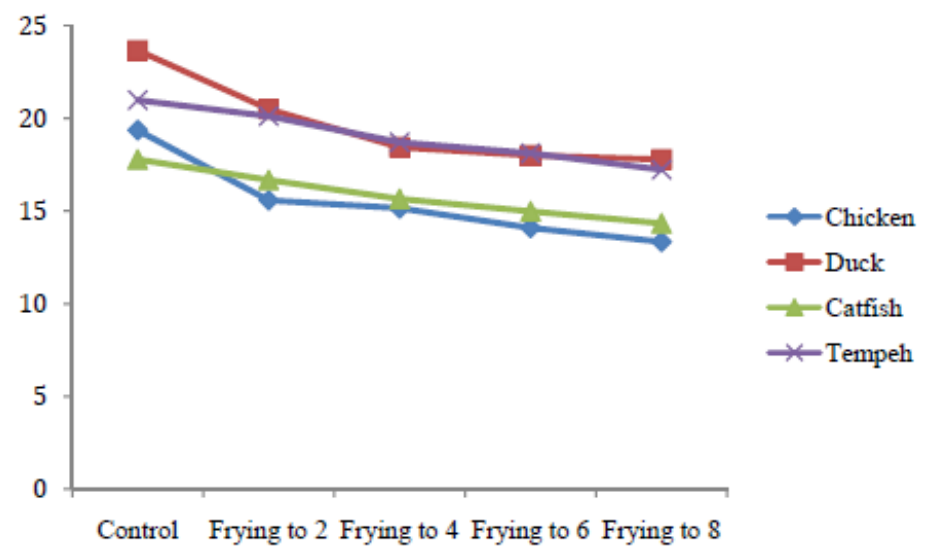

Figure 3. Graph of protein level of fried chicken, fried duck, fried catfish, and fried tempe in any frying frequencies 
Figure 3 shows that the treatment of repetitive use of cooking oil has a significantly influence to the protein level of fried product $(\mathrm{P}<0.05)$. Here, the lowest protein level is found on fried chicken in the $8^{\text {th }}$ frying at $19.00 \%$. This is because of the effect of the repetitive use of cooking oil that not only makes the oil damage but also brings an effect on the fried food products. This is stated by Ketaren (1986) that the damage in cooking oil during a frying process will badly impact on the quality and protein level of the fried foodstuff. This statement is then more explained by Almatsier (2005) saying that the structure of protein is commonly unstable, thus enabling it easily to change in solution when having a change on $\mathrm{pH}$, radiation, light, or high temperature. Such protein is called as the protein denaturation that has a number of different physical and physiological characteristics compared to the initial protein.

The result of the analysis of mode shows the significant influence $(a=0.05)$ to the protein level from the initial frying to the $8^{\text {th }}$ frying. Ericson, 2002) further explains that the main factor towards the decrease of protein value of foodstuff during the process is the reaction of non-enzymatic browning (Maillard reaction). The Maillard reaction with amount of sugar (particularly the reducing sugar) can lead to a reduction in protein quality that is the removal of amino acid residue.

The processing of four food products shows a protein denaturation causing the decrease of protein level that is different depending on the processed materials. The decrease of the protein level is caused by the razemisation of amino acid, and the change of $\mathrm{L}$ form into $\mathrm{D}$ form. This, as a consequence, can cause the decrease of the nutrient value of the protein due to the decrease of availability of essential amino acids. The foodstuff processing that is not well controlled, furthermore, can cause the decrease of nutrient level of the foodstuff. In general, the nutrient foodstuff processing can be done physical, chemical or biological manners.

\subsection{Free Fatty Acids}

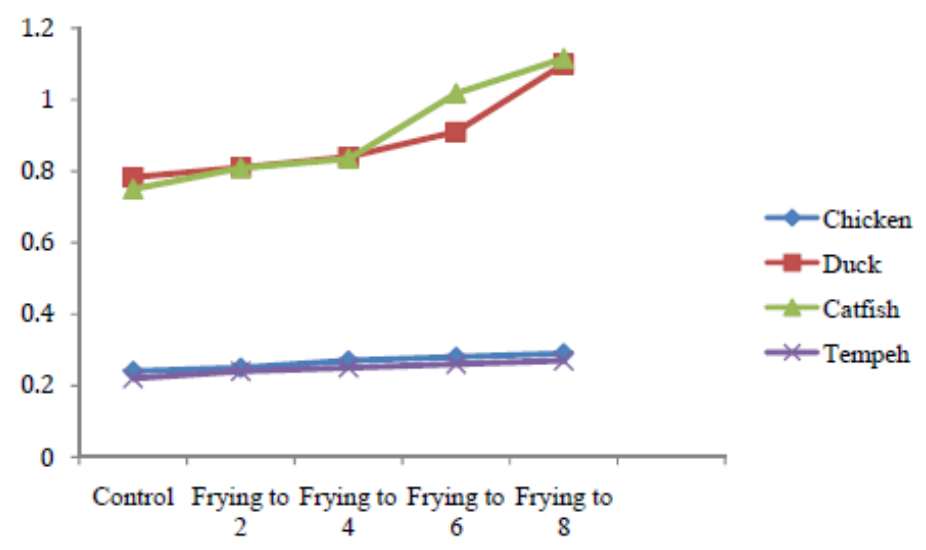

Figure 4. The graph of the level of free fatty acids of products of fried chicken, fried duck, fried catfish, and fried tempeh in any frying frequencies

The acid numbers refer to the amount of $\mathrm{mg} \mathrm{KOH}$ required to neutralize the free fatty acids present in one gram of fats. The large acid number shows the large free fatty acids originated from fat hydrolysis due to the treatment process. The higher the numbers of the acids is, the lower the quality of the fat in foodstuff will be (Sudannadji et al., 1996). Due to the treatment of types of the fried products and the frying frequencies, the trend of the average of free fatty acids is obtained as in Figure 4.

Free fatty acids refer to the hydrolytic result of triglyceride. When the oil is used, the free fatty acids are produced from the initial process through the process of oxidation decomposition. However, at the further phase, the free fatty acids are produced from the hydrolytic process due to the presence of water. The oil used in the frying process is at risk of the formation of free fatty acids in consideration to the heat treatment with high temperature causing the increase of free fatty acid content. This is in line with the statement of Andarwulan, Sadikin and Winarno (1997) saying that the cooking oils being used in the frying process mostly heated at the temperature ranging at $162-196^{\circ} \mathrm{C}$ with the condition of soaked foodstuff and continually used will form the free fatty acids in the cooking oil.

The result of analysis of free fatty acids on the oil combination from the fried food and the duration of frying 
process as shown in Figure 4 shows that the level of the free fatty acids increases in the frying duration. Here, the highest percentage is found at the $8^{\text {th }}$ frying of the fried catfish at $1.11 \%$ and the lowest percentage, by contrast, is found at the $2^{\text {nd }}$ frying of fried chicken at $0.25 \%$.

The result of Analysis of Variance shows that the cooking oil of fried food has a significant effect on the level of free fatty acids of fried food. This result also shows that the repetitive use of cooking oil can have a significant effect on the percentage of free fatty acid level.

The increase of free fatty acid level is related to the more frequent use of cooking oil and the presence of water in oil leading to the occurrence of hydrolysis in oil. This is in line with the statement of Aidos et al. (2001) saying that the increase of the level of free fatty acid is because the water level in oil is not so high at the initial frying but in the next frying process, the water level in oil increases. The existence of the water in oil can accelerate the hydrolysis process of cooking oil in which the longer the use of cooking oil is, the higher the content of free fatty acids will be formed. Based on the data above, the highest level of free fatty acids is at $1.1 \%$ - meaning that has passed the threshold of percentage of free fatty acid as regulated by SNI 01-3741-1995 informing that the requirement of the content of free fatty acids is $0.30 \%$ in maximum.

The presence of water content and air in foodstuff can more increase the oil damage and it can be analyzed by calculating the level of free fatty acid of the oil. The longer the use of the cooking oil is, the higher the content of the free fatty acid will be. This is in line with the result of the study on the damage of oil stating that the composition of the fried foodstuff will affect the damage of oil that can be accelerated by the presence of water, protein, carbohydrate and other materials (Ericson, 2002).

The presence of free fatty acid indicates a decline in quality or damage on oil. The damage of oil during the frying process will affect the quality and nutrient values of the fried foodstuffs. The damaged oil due to the oxidation and polymerase will result in the uninteresting appearance and tasteless flavor and the damage on a part of vitamins and essential fatty acid content in the oil. According to deMan (1999) the frying frequency can cause the physical feature's change, heavier oil, unexpected odor and taste and more turbid oil. The occurrence of the increase of free fatty acid level is also caused by the long time of storage. During the storage, oil and fat experience a number of physiochemical transformation that can be caused by the hydrolysis and oxidizing process. An inappropriate storage in a long time can cause the breakdown of triglyceride binding on oil then forming glycerol and free fatty acids (deMan, 1999).

In Figure 4, it can be seen that the percentage of the free fatty acids in all samples increases. The free fatty acids have been already present in the oil before the first use. This is now that the oil used by the vendors is the bulk oil that probably has previously been used by other people. Among societies, such oil is known as Jelantah oil (used or wasted oil). The cooking oil that has been repetitively used will have a change in the level of free fatty acids and peroxide number. From the chemical perspective, the Jelantah oil contains carcinogenic compounds namely free fatty acid, peroxide number, iodine number, saponification number and water content that has a value above the standard of SNI.

Similar with the peroxide number, the level of free fatty acids in Jelantah oil will increase along with the length of the frying process (deMan, 1999). This is agreed by Ketaren (1986) saying that the amount of free fatty acids will more increase with the length of the frying process. The fatty acids contained in the cooking oil are used as an indication of the cooking oil quality. The hydrolysis reaction is easier to occur in the oil containing the short-chain and unsaturated fatty acids compared to the long-chain and saturated one. It is due to that the short-chain and unsaturated fatty acids are more soluble in water. The addition of new oil in the frying process can slow down the occurrence of hydrolysis reaction.

The hydrolysis of oil and fat can produce the free fatty acids that can affect the flavor and odor of the material. Hydrolysis can be caused by the water in the fat or oil or enzymatic activity (deMan, 1999). 


\subsection{TBA Numbers}

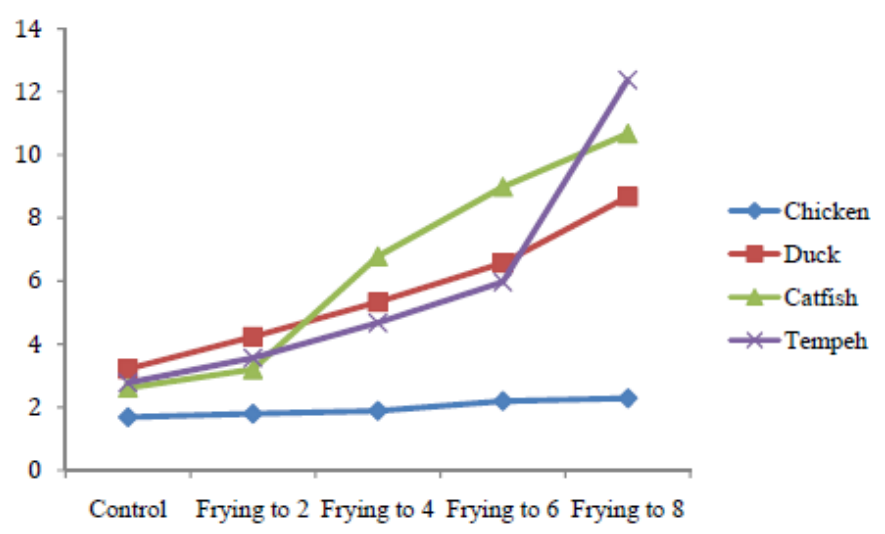

Figure 5. The graph of the level of tba of products of fried chicken, fried duck, fried catfish, and fried tempeh in any frying frequencies

The frequently used cooking oil might have rancidness. The rancid oil containing monoaldehyde is commonly called as TBA numbers. The high number of TBA in oil is caused by a heating process at a high temperature and the oxidation process - leading the peroxide decomposition to malonaldehyde - thus making the level of malonaldehyde in oil more increase. This is in line with Ketaren (1986) stating that the damage in fat can occur because of oxidation either in enzymatic or non enzymatic manner. The examination on the fat damage can be conducted by examining the content of peroxide or the amount of monoaldehyde that is commonly called as TBA (thio-barbituric acid) numbers.

Figure 5 shows the result of analysis on the TBA number of oil based on the oil treatment of the fried food and duration of the frying process. It is shown from the figure that the TBA numbers in oil is getting more increase based on the repetitive frying process (mg Malonaldehyde/kg). The fifth frying of oil from the fried tempe indicates the highest value reaching at 12.38 , while the lowest one at the first frying of oil from the fried chicken is at 1.68 (mg Malonaldehyde $/ \mathrm{kg})$.

The result of the Analysis of Variance shows that the oil in fried food significantly affect the thio-barbituric acid from the fried food, while the result of the Analysis of Variance on the repetitive frying shows a significant effect on the thio-barbituric acid. The increase of TBA numbers in oil is due to the repetitive frying that leads to the process of oxidation and makes the oil rancid. This is in line with the statement of Sudarmadji et al. (2003) saying that a repetitive frying can make absorbance higher and then easy to be rancid and the high value of TBA can also make the oil more rancid.

\subsection{Peroxide Numbers}

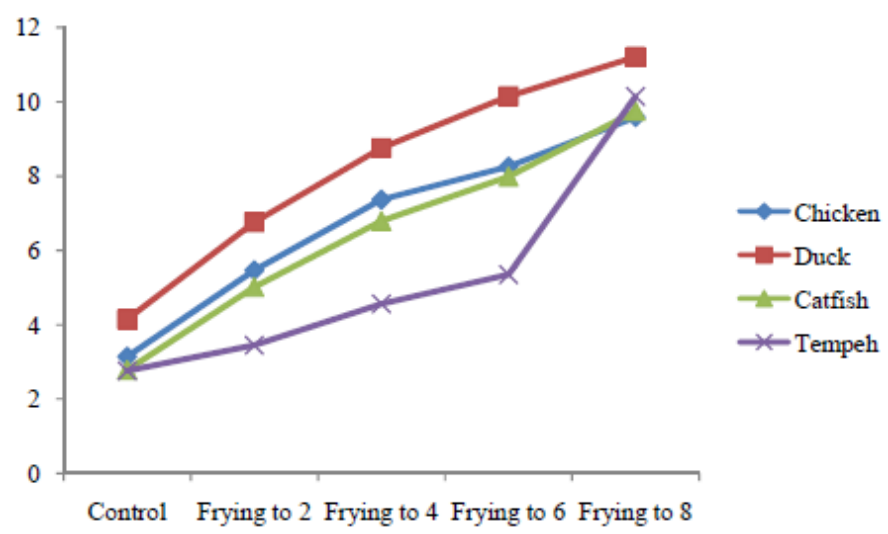

Figure 6. The graph of the level of peroxide numbers of products of fried chicken, fried duck, fried catfish, and fried tempeh in any frying frequencies 
The result of the calculation to the peroxide numbers shows an increasing trend along with the more frequently repetitive frying. The peroxide numbers in fresh oil as many as the use at high temperature during the frying process can stimulate the emergence of oil oxidation. According to deMan (1999) in each increase of temperature at $10^{\circ} \mathrm{C}$, the speed rate of oxidation will be twice higher in increase. The speed of fat oxidation will increase along with the increasing temperature and will decrease at a low temperature. The speed of peroxide accumulation during the process of oil aeration at the temperature of $100-115^{\circ} \mathrm{C}$ is twice higher than at the temperature of $10^{\circ} \mathrm{C}$ (Ketaren, 1986).

The test result of ANOVA shows that the repetitive frying process has a significant effect on the peroxide number with $(\mathrm{P}<0.05)$. The further test result shows that there is no any difference in control to peroxide number under the treatment of the first repetitive frying, while in the next repetition, it shows a difference at the value of $p<0$. 05 .

The research result of Alyas, Abdullah, Idris (2006) shows the significant increase of peroxide numbers along with the increase of temperature and time of frying. Aidos et al. (2001) in addition reported that the increase of the peroxide number is significant with the increase of the storage temperature. This result shows the synergy effect of the high temperature and time on peroxide numbers. The measurement of the peroxide number basically refers to the measurement of the peroxide and hydro peroxide level formed at the initial phase of fat oxidation reaction. The high peroxide numbers indicate the fat or oil that has already had oxidation, but the lower number does not always mean to show the condition of premature oxidation. The lower peroxide number might be caused by the rate of formation of new peroxide lower than the rate of its degradation to be other compounds in consideration to that the peroxide level soon experiences degradation and reacts with other substances (Raharjo, 2000).

Fat oxidation by oxygen can happen spontaneously if the fatty substance has a contact with air. Meanwhile, the rate of the oxidation process depends on the type of the fat and the storage condition (Ketaren, 986). Jelantah oil is distributed unpackaged with higher light compared to the packaged oil. The exposure of oxygen, light and high temperature is the factors for oxidation.

The use of high temperature during the frying process can stimulate the oil oxidation. According deMan [1999] each of the increasing temperature at $10{ }^{\circ} \mathrm{C}$ increases twice higher. The rate of the fat oxidation will increase along with the increasing temperature and come to decrease at a low temperature. The rate of peroxide accumulation during the process of oil aeration at the temperature of $100-115{ }^{\circ} \mathrm{C}$ twice higher than at the temperature of $10^{\circ} \mathrm{C}$ (Ketaren, 1986).

Peroxide is formed at the phase of oxidation initiation. At this phase, hydrogen is taken from the olefins and results in free radical. The presence of the light and metal play a role in the process of taking hydrogen. The formed free radical reacts with the oxygen forming peroxide radical then can obtain hydrogen from the other unsaturated molecule resulting in new peroxide and free radical (deMan, 1999; Ericson, 2002).

\section{Conclusions and Suggestion}

Based on the result of the research, it can be concluded that the repetitive use of cooking oil not only damages the quality of the cooking oil but also leads to the reduction in quality of the fried foodstuff. This can be shown through the peroxide number, ALB, TBA, p-Anisidine and the increasing water level. If this is still not well concerned, it can badly affect the health of consumers.

\section{References}

Aidos, I., Padt, A. F. D., Remko, B. M., \& Luten, J. B. (2001). Upgrading of Maatjes herring by-products: production of crude fish oil. Journal Agriculture and Food Chemistry, 49(8), 3697-3704. http://dx.doi.org/10.1021/jf001513s

Almatsier, S. (2005). Prinsip Dasar Ilmu Gizi. published by PT Gramedia Pustaka Utama, Jakarta.

Alyas, S. A., Abdullah, A., \& Idris, N. A. (2006). Change of Carotene Content During Heating of Red Palm Olein. Journal of Oil Research, 99-120.

Andarwulan, A., Sadikin, Y. T., \& Winarno, F. G. (1997). Pengaruh lama penggorengan dan penggunaan adsorben terhadap mutu minyak goreng bekas penggorengan tahu-tempe. Teknol Bulletin and Food Industry, $8(1), 40-45$.

deMan, M. J. (1999). Principles of Food Chemistry. (3 ed.). Aspen Publisher, Inc. Gaithersburg, Maryland. http://dx.doi.org/10.1007/978-1-4614-6390-0

Ericson, M. C. (2002). Lipid Oxidation of Muscle Foods. In C. C. Akoh \& B. D. Min (2nd ed.). Food Lipid: 
Chemistry, Nutrition, and Biotechnology. Marcel Dekker Inc. New York-Basel. http://dx.doi.org/10.1201/9780203908815.ch12

Fardiaz, D. (1991). Kimia Lipida Pangan. Laboratorium Kimia dan Biokimia Pangan Pusat Antar Universitas Pangan dan Gizi Intsitut Pertanian Bogor. Bogor.

Ketaren, S. (1986). Pengantar Teknologi Minyak dan Lemak Pangan. UI-Press. Jakarta.

Raharjo, S. (2006). Kerusakan Oksidatif pada Makanan. Gadjah Mada University Press.

Raharjo, S. (2008). Melindungi Kerusakan Oksidasi pada Minyak Selama Penggorengan dengan Antioksidan. Food Review Indonesia, 3(4).

Winarno, F. G. (2004). Kimia Pangan dan Gizi. PT Gramedia Pustaka Utama, Jakarta.

\section{Copyrights}

Copyright for this article is retained by the author(s), with first publication rights granted to the journal.

This is an open-access article distributed under the terms and conditions of the Creative Commons Attribution license (http://creativecommons.org/licenses/by/3.0/). 